\title{
HERITAGE TOURISM IN UBEDA Y BAEZA (SPAIN). WORLD HERITAGE REINASSANCE CITIES
}

\author{
Jesús Claudio PÉREZ-GÁLVEZ \\ University of Cordoba, Department of Applied Economics, \\ Plaza Nueva Square, Córdoba, Spain, e-mail: dt1pedaj@uco.es \\ Tomás LÓPEZ-GUZMÁN* \\ University of Cordoba, Department of Applied Economics, \\ Adarve Street, Córdoba, Spain, e-mail: tomas.lopez@uco.es \\ Miguel Jesús MEDINA-VIRUEL \\ University of Cordoba, Department of Applied Economics, \\ Plaza Nueva Square, Córdoba Spain, e-mail: mjmedina@uco.es \\ Mónica TORRES-NARANJO \\ University Polytechnic of Litoral, Faculty of Social and Humanistic Sciences, \\ Km 30.5. Vía Perimetral, Guayaquil, Ecuador, e-mail: mmtorres@espol.edu.ec
}

\begin{abstract}
Citation: Pérez-Gálvez, J.C., López-Guzmán, T., Medina-Viruel, M.J., \& Torres-Naranjo, M. (2019). HERITAGE TOURISM IN UBEDA Y BAEZA (SPAIN). WORLD HERITAGE REINASSANCE CITIES. GeoJournal of Tourism and Geosites, 26(3), 808-820. https://doi.org/10.30892/gtg.26311-399
\end{abstract}

\begin{abstract}
This research is focused on the cities of Úbeda and Baeza and aims to characterize the type of tourists that visit them. The study investigates the characteristics of the trip, as well as the assessment that visitors make of the tourist attributes, recognizing differences between the various types of tourists. For this, a segmentation was made based on the cultural and patrimonial motivations of the tourists. This research uses the multivariate technique of grouping cases (K-means clusters) to analyse the similarity existing among the surveyed persons. From the groups or segments obtained, statistics and measurements of association were applied that provide the information necessary to study the possible trends of association existing between variables from a table of bidimensional contingencies. In the same way, non-parametric statistical procedures were used (Kruskal-Wallis $\mathrm{H}$ test and the Mann-Whitney U test). The visitors have been segmented according to their perception of the heritage and their cultural interest resulting in four types of tourists being identified: alternative tourist, cultural tourist, emotional tourist and heritage tourist. Also, the results reveal a higher valuation among tourists who present cultural motivations. This article contributes to complete the academic literature existing on the links of the tourist with the historical and monumental heritage that he visits, and with the tourist's behaviour.
\end{abstract}

\footnotetext{
* Corresponding author
} 
Heritage Tourism in Ubeda y Baeza (Spain).

World Heritage Reinassance Cities

Keywords: Renaissance, Cultural and heritage tourism, Tourist valuation, Tourist characteristics, Úbeda and Baeza, Spain

\section{INTRODUCTION}

This research intends to strengthen academic literature, contributing with tourism experiences in World Heritage Sites (WHS). Its fundamental objective is to analyze the relationships between the visitor's perception of the historical and/or monumental heritage that they visit and their behavior. To this end, a questionnaire was applied to a representative sample of tourists who visited the cities of Úbeda and Baeza (Spain). It provided information regarding both their socio-demographic characteristics (age, sex, profession or level of studies) and their motivations, the perception of the heritage place visited or the assessment of the city's tourist attributes. In this sense, Adie and Hall (2017) indicate the need to conduct studies in WHS. The geographical area object of this research focuses on two of the greatest exponents of the Spanish Renaissance: the cities of Úbeda and Baeza (Jaén). These two cities are located in the región of Andalucía, in southern Spain. The Spanish Renaissance is the expression used to define the influence of the artistic, architectural and cultural movement originated in the 15th century in Italy. The Renaissance featured artists such as Leonardo Da Vinci, Titian, Rafael Sanzio, Michelangelo Buonarroti or Filippo Brunelleschi. This artistic movement known as the Renaissance extends from Italy in the late 15th century to the rest of Western Europe.

It takes place in Spain in two stages called "Plateresque" and "Purism". It should be noted that the rise of the Spanish Renaissance was during the first half of the 16th century. In Spain, the Renaissance manifests itself in literature and art. To highlight the influence of this artistic movement in the Iberian country, the Renaissance pieces found in Andalusia can be studied. The Andalusian Renaissance has leading artists in the expression of their architecture as Andrés de Vandelvira. The cities of Úbeda and Baeza have an evident Renaissance style that allowed them to be declared (in 2003) as a World Heritage Site by UNESCO. While there is broad academic literature that addresses the relationship between a WHS and tourism, the existing evidence is not conclusive at this time. Ribaudo \& Figini (2016), to elucidate the impact that a WHS has on a tourist destination, gathered some questions present in previous studies by different authors (Poria et al., 2006, Poria et al., 2013, Su \& Wall, 2011). In this sense, they deal with the influence that the inscription of a place in the UNESCO lists has on the promotion and management of the destination, the social and economic impact that is generated by said registration, the analysis of the perceptions and attitudes of the visitors in WHS or the impact of the inscription on the UNESCO list on tourism flow.

This research contributes to the academic literature with an empirical study that allows a better understanding of the visitors' behavior in a WHS. This allows an efficient management of the destination and the design of strategies by the authorities and operators involved in the tourism sector. To achieve this, the relationship between tourists and the artistic and cultural heritage in the cities of Úbeda and Baeza was analyzed in order to examine what is defined in literature as heritage tourism. According to Nguyen and Cheung (2014), heritage tourism involves visiting and having experiences in places that have an artistic and monumental heritage. Poria et al. (2006) establish that this experience supposes a better understanding by visitors of the destination through what this cultural heritage represents for the tourists. Also, Poria et al. (2003) establish 
that visiting patterns in a destination are related to the perception that visitors have and their identification of the place with their own culture and, therefore, they conclude that their behavior will be different from the rest of the tourists. It is noteworthy that McKercher (2002) establishes two dimensions to make a segmentation of tourists visiting a cultural destination: the first being the cultural motivation that a visitor has to move to a place, and the second being the depth of their knowledge regarding this type of cultural heritage. Following the model developed by Poria et al. (2003) and McKercher (2002), it is intended to make a segmentation of tourists who go to cultural destinations such as Úbeda and Baeza. To achieve the objectives of this research, the research is structured as follows: after this first section, the second section critically analyzes the main findings of the academic literature, the third section presents the methodology used, while the fourth section highlights the main results of the investigation. Finally, the conclusions are exposed in the fifth section and with the bibliographic references used.

\section{LITERATURE REVISION}

\section{Heritage tourism}

The design of strategies aimed at improving the management of a tourist destination is a relevant aspect in the agenda of the makers of public policies in the tourism sector. Therefore, understanding the behavior of visitors is important for both public administrations and the private sector to carry out a good planning and implementation of these strategies. In this sense, the analysis of the links between visitors and the artistic and monumental heritage (or cultural heritage) of a place contributes to deepen knowledge about heritage tourism. Nguyen and Cheung (2014) define heritage tourism as an experience in a cultural destination, and this implies, therefore, visiting certain places that are part of the culture of those tourists.

Visiting a WHS can be thought of as the journey made by a tourist to know their own heritage, to understand and reinforce their own culture through the visit (Poria et al., 2006). In accordance with the findings of Poria et al. (2003), the perception of a tourist about a certain destination, and set as part of their own cultural heritage, is linked to their visiting patterns, which can lead to a different behavior than other visitors.

\section{Segmentation}

In order to carry out both an efficient management of a tourist destination and a design of the strategies according to the existing demand in historic-heritage sites, it is necessary to identify and segment the tourists (Saipradist \& Staiff, 2007). Likewise, it is also necessary to differentiate the World Heritage Tourist among other visitors (Adie \& Hall, 2017). The determination of different types of heritage tourists, motivation, behavior and perception helps to understand these differences and also allows a more precise identification of who is called a heritage tourist (Nguyen \& Cheung, 2014). Therefore, the segmentation of tourists that come to a WHS is basic for the managers of a cultural destination to do their job. As a result, the tourists that go to a WHS and are attracted to the artistic and historical heritage can be identified. The segmentation of this type of tourists is presented in different previous investigations. Among these investigations, the one carried out by Silberberg (1995) can be highlighted as the following typologies are established: accidental cultural tourist, adjunct cultural tourist, in part cultural tourists and greatly cultural tourists. Accordingly, Mckercher (2002) establishes different typologies based on the importance of cultural motivations and the depth of the knowledge that travellers have of that place. Namely: pragmatic tourist, contemplative tourist, casual tourist, incidental tourist and fortuitous tourist. It should be noted that Nguyen and Cheung (2014) replicated this model in a subsequent investigation. 
On the other hand, Poria et al. (2003) classify tourists according to their perception of the heritage of the place, as well as the relationship between the destination and the tourist. They establish the following groups of tourists: tourists who are in places not related to their own heritage; tourists who visit places where there is an important part of their heritage, and tourists who are not aware that this place is part of their heritage. Taking this into consideration, the hypotheses to be examined would be the following:

H1: Some tourists have emotional experiences that lead them to feel more than to contemplate the place they visit.

H2: Considering the emotional experiences and the cultural interest in a WHS, there are different types of visitors.

\section{Socio-economic characteristics of the foreign tourist}

For both public and private managers, the knowledge that can be obtained about the sociodemographic profile of tourists is crucial to efficiently manage a tourist destination. Therefore, one of the topics most addressed in the academic literature is the characterization of the socioeconomic aspects of the tourist who visits a destination.

In this sense, it has been analyzed if the gender of visitors is a key element in terms of attracting tourists to a certain destination (Al-Rousan et al., 2019). However, the empirical evidence does not indicate conclusive results in this case. There are several studies that evidence that women prefer these cultural places (Vong \& Ung, 2012; Nguyen \& Cheung, 2014; Remoaldo et al., 2014; Ramires et al., 2017). On the other hand, there are also studies that show the contrary and conclude that men are the ones who are most attracted to these destinations (Correia et al., 2013; Antón et al., 2017; Chen \& Huang, 2017; Hall, 2017). Controversy is also present in relation to another of the variables analyzed in this type of studies: age. Thus, empirical evidence indicates quite different age brackets. For example, Chen and Huang (2017) identify tourists between 21 and 35 years old; Anton et al. (2017) find ages between 30 and 44 years; Remoaldo et al. (2014) identify ages that range from 26 to 45; Huh, Uysal and McCleary (2006) show ages that range between 38 and 47 years; and Correia et al. (2013) and Ramires et al. (2017) establish ages over 45 years. In relation to the level of training, the existing academic literature indicates that visitors who go to destinations where an artistic and monumental heritage predominates have a certain level of university academic training.

As a matter of fact, this is the most representative group (Silberberg, 1995; Huh et al., 2006; Correia et al., 2013; Remoaldo et al., 2014; Antón et al., 2017; Ramires et al., 2017; Adie \& Hall, 2017). In the same sense, Chen and Huang (2017) mention that it should be taken into account that another important group of tourists is made up of students, since this group also usually goes to these destinations.Likewise, most of the empirical studies (Chen \& Huang, 2017; Antón et al., 2017; Ramires et al., 2017) indicate that visitor's income that come to these places is average or above average. These findings are complemented by the results found regarding the level of academic training that characterizes this group of tourists (Huh et al., 2006; Correia et al., 2013; Bright \& Carter, 2016; Chen \& Huang, 2017; Antón et al., 2017; Ramires et al., 2017). Following the existing literature, the hypotheses to be tested would be the following:

H3: The cultural interest in a WHS increases with the age of the tourist.

H4: Travelers with a greater cultural interest in a WHS have more academic training.

$\mathrm{H}_{5}$ : Tourists with a greater cultural interest in a WHS generate a greater economic impact on the visited destination.

\section{Evaluation of the attributes of the destination}

Lew (1987) points out that the set of elements that attract the visitor represent the attributes of a tourist destination and that the ability to attract tourists will be subject to 
the social and personal benefits that may be perceived by the individuals who visit the place. In this way, the attributes of the destination constitute a fundamental factor for the tourist to have a memorable experience (Tung \& Ritchie, 2011; Kim, 2014). Therefore, if the tourist has a rewarding experience in that place, their level of satisfaction increases and this implies having greater loyalty towards the destination and, consequently, promoting it (Ozdemir et al., 2012). For this, some key elements must be combined, such as heritage, infrastructure, gastronomy or cultural exchange (Chi \& Qu, 2008; Kim \& Brown, 2012). However, it is necessary to remember that not all attributes provide a competitive advantage of the place with the same intensity (Prayag, 2008). Some scientific studies contribute to understanding how attributes generate satisfaction and create a target image. Thus, it has been possible to determine which are the key attributes to be able to evaluate a destination and to establish the components that collect said attributes. These include gastronomy and city safety (Driscoll et al., 1994; Dwyer \& Kim, 2003; Beerli \& Martín, 2004; Chi \& Qu, 2008; Crouch, 2011; Chandralal \& Valenzuela, 2013; Kim, 2014).

\section{METHODOLOGY}

\section{Questionnaire and procedure}

The methodology used for the development of this research was based on the realization of a fieldwork, based on a structured questionnaire that was passed on to a representative sample of tourists who visited the cities of Úbeda and Baeza. Among the options that were available to collect the information, the design chosen was a closed questionnaire to be self-administered. In order to guarantee its validity, the formulation of the items was based on different previous investigations (McKercher, 2002; Poria et al., 2003; Mckercher \& du Cros, 2003; Correia et al., 2013; Remoaldo et al., 2014). From an initial set of items, a process of sorting them in three phases was followed. Namely: first, a researcher specialized in the tourism sector analyzed the proposed items; second, the resulting questionnaire was reviewed by several people in charge of the tourist activity in those cities; third, a pre-test was made to 50 tourists. The final version of the questionnaire sought to have the maximum understanding of the questions and the greatest adjustment of the answers to achieve the objectives set in the research.

Likewise, the questions were intended to be straightforward to not extend the interview too much to the visitors who did the survey. The questionnaires were carried out in different places of the historical centers of both cities, obtaining a similar number of questionnaires in both cities, and with the premise that the tourist taking part on the survey had already spent certain time in the destination and, therefore, could give a wellfounded opinion (Correia et al., 2013; Remoaldo et al., 2014). As for the structure of the questionnaire, it was divided into two large blocks: a first block focused on the analysis of the emotional perceptions of the historical and monumental heritage visited and the assessment made of the main attributes related to the visit; and a second block that collected the sociodemographic characteristics of visitors such as age, gender, economic level or degree of education. The questions in the first block of the questionnaire were answered through a five-point Likert scale. The questions in the second block were closed. The questions were formulated in a positive and negative sense to avoid acquiescence.

The questionnaires were conducted by a team of interviewers linked to the University of Córdoba (Spain) and the municipalities of Úbeda and Baeza. They were passed in three languages (Spanish, English and French). Each tourist chose the language of the questionnaire. A total of 561 questionnaires, of which 528 were valid, were completed between the months of January and July 2017. The questionnaires were carried out on different days and at different times in the historic centers of the two cities 
to try to collect the widest possible range of people and situations. A non-probabilistic technical sampling, commonly used in this type of research, was used, which means that tourists interviewed were available to do the survey be in a given time and space (Finn et. al., 2000). It was not stratified by age, gender, nationality, level of education or by any other variable, since there were no previous studies to support this stratification. The rejection rate to the questionnaire was low and not significant depending on any of the variables. The questionnaire did not last longer than 10 minutes.

\section{Sample and data analysis.}

This research is specifically about the national and international tourist who visits the Renaissance Monumental Ensembles of Úbeda and Baeza, regardless of whether they stay overnight or not, or if they visit other places in the region of Andalusia. The number of tourists who visited these cities in 2016 was 70,537 (Ministry of Economy and Knowledge, 2016). Therefore, based on this number of visitors and for guidance only in the case of random sampling, the sampling error for a confidence level of $95 \%$ would be $\pm 4.25 \%$. The tabulation and the statistical analysis of the data have been carried out using the SPSS v. 23 statistics program. Statistics have been applied to assess the reliability and validity of the questionnaire responses (Cronbach's alpha).

The multivariate technique of grouping cases (K-means conglomerates) has been used in order to analyze the similarity between the respondents. The discriminant analysis technique has been used to validate the grouping of cases obtained in the cluster analysis. From the groups or segments obtained, statistical and association measures that provide the necessary information to study the possible patterns of association between variables from a two-dimensional contingency table have been applied. Likewise, nonparametric statistical procedures ( $\mathrm{H}$ of Krustal-Wallis and the $\mathrm{U}$ of Mann-Whitney) have been used in order to analyze significant differences between groups of the sample.

\section{RESULTS}

\section{Perception of historical heritage and tourist segmentation}

In order to analyze and segment the sample, surveyed tourists were asked to assess the emotions perceived when visiting historical and monumental heritage. For this, the model of Poria et al. (2003) and the Mckercher model (2002) were used. The different items used are shown in Table 1 . The Cronbach alpha coefficient of the final scale reaches a value of 0.767 , indicative of a meritorious internal consistency between the elements of the scale. The critical level (p), associated with Friedman's statistical $\chi^{2}(570,099)$ of the analysis to test the null hypothesis that all the elements of the scale have the same mean, is less than 0.001, thus rejecting the hypothesis that the means of the elements are equal.

A non-hierarchical conglomerate analysis was carried out to elaborate similar groups and to know their characteristics. Under the criterion of maximizing the variance between typologies, and minimizing the variance within each of them, the best solution that meets these criteria establishes four clusters or segments. For its confirmation, the $\mathrm{H}$ test of Kruskal-Wallis (1952) was carried out. Table 1 shows the characterization of the clusters based on the means of the four items that aims to measure the tourist's perception of the visited heritage (Poria et al., 2003) and of the two items that evaluate their cultural motivation regarding the destination (McKercher, 2002).

The four segments detected are the following: (1) alternative tourist (2) cultural tourist, (3) emotional tourist and (4) heritage tourist. The first of the segments is made up of $9.3 \%$ of the surveyed tourists, with the group that registers significant low records in each of the items. This cluster is called an alternative tourist, and groups visitors whose cultural identity is not related to the heritage they visit. The second group represents $44.3 \%$ of the sample and is characterized by grouping tourists whose cultural identity is 
not related to the heritage visited, although they have a cultural interest in the destination. This cluster is called a cultural tourist. The third group comprises $19.7 \%$ of the respondents, scoring intermediate scores in the items related to the perception of historical heritage and low records in relation to the cultural interest for the destination. This cluster has been called an emotional tourist. The fourth of the segments is characterized by a high emotional connection with the visited heritage and cultural interest for the destination. It has been called a heritage tourist (26.7\%). Within this last group it is observed that $57 \%$ of the surveyed tourists share a common identity that is related to the visited destination. These tourists are those with a greater proximity to the selected destination, sharing, therefore, the cultural identity of the Andalusian Renaissance (region of belonging to the cities of Úbeda and Baeza).

Table 1. Characterization based on perception of historical heritage and cultural interest

\begin{tabular}{|c|c|c|c|c|c|c|}
\hline & \multicolumn{4}{|c|}{ Tourist Clusters } & \multicolumn{2}{|c|}{ Kruskal-Wallis H } \\
\hline & $\mathbf{1}$ & 2 & 3 & 4 & $x^{2}$ & Sig. \\
\hline \multicolumn{7}{|c|}{ Perception of Historical Heritage (Average) } \\
\hline $\begin{array}{l}\text { My visit to the historical heritage of } \\
\text { the city moved me }\end{array}$ & 3.10 & 3.41 & 3.79 & 3.80 & 21.673 & $<0.000$ \\
\hline $\begin{array}{l}\text { During my visit I felt as part of the } \\
\text { heritage }\end{array}$ & $\mathbf{2 . 0 6}^{(*)}$ & $2.59^{(*)}$ & 2.93 & 3.04 & 28.457 & $<0.000$ \\
\hline $\begin{array}{l}\text { My visit to the historical heritage of } \\
\text { the city made me feel good }\end{array}$ & 3.94 & 4.11 & 4.11 & 4.06 & 1.381 & $<0.710$ \\
\hline $\begin{array}{l}\text { My visit to the historical heritage of the } \\
\text { city has contributed to my education }\end{array}$ & $2.84^{(*)}$ & $3 \cdot 54^{(*)}$ & $3.89^{(*)}$ & $4.04^{(*)}$ & 51.089 & $<0.000$ \\
\hline \multicolumn{7}{|l|}{ Cultural Interest (Average) } \\
\hline $\begin{array}{l}\text { To know the city's wealth of } \\
\text { monuments and history }\end{array}$ & $1.78^{(*)}$ & $4 \cdot 50^{(*)}$ & $3.60^{(*)}$ & $4.98^{(*)}$ & 257.055 & $<0.000$ \\
\hline $\begin{array}{l}\text { To get a deeper knowledge of the } \\
\text { city's heritage }\end{array}$ & $1.33^{(*)}$ & $\mathbf{3 \cdot 3 1} \mathbf{1}^{*}$ & $\mathbf{2 . 1 1}^{(*)}$ & $4.86^{(*)}$ & 429.188 & $<0.000$ \\
\hline
\end{tabular}

The results obtained in this research allow to contrast the first two research hypotheses: first, regarding the results obtained by the previous academic literature (Urry, 1990; Bruner, 1996; Cheung, 1996; Poria et al., 2003; Poria et al., 2006), some tourists have emotional experiences that lead them to feel the place they visit as their own (H1); second, there are different types of tourists attending to the emotional experiences and cultural interest for the visited heritage (H2) (Silberber, 1995; McKercher, 2002; Mckercher \& Du Cros, 2003; Poria et al., 2003; Poria et al., 2006).

\section{Socio-economic characteristics of the foreign surveyed tourist}

From the 528 tourists surveyed, $57.1 \%$ were men and the remaining $42.9 \%$ were women. There were no significant differences in the data collection over the different months. The visitors surveyed are, in general terms, young. Table 2 reflects how $59.6 \%$ of the sample are less than 40 years old. Older tourists are more representative in those segments that show a greater cultural interest for the destination (statistical $\mathrm{H}$ of KruskalWallis $=8,387, \mathrm{p}=0,039$ ). This result allows to contrast another of the proposed research hypothesis: the cultural interest for a WHS increases with the age of the tourist (Tse \& Crotts, 2005) (H3). Younger tourists - that is, the group under 30- usually travel accompanied by their partner and/or friends, co-workers or alone, detecting an association between age and the company with which they travel (contingency coefficient 
Heritage Tourism in Ubeda y Baeza (Spain).

World Heritage Reinassance Cities

$=0.484, p=0.000$ ). The tourist aged between 40 and 49 years old usually travels with their partner and children. Regarding the professional category of tourists doing the survey, full-time salaried workers, public employees and students stand out.

The level of academic training of the respondents is medium-high, as shown in Table 2. It is important to highlight the considerable percentage of university graduates, since $59 \%$ of the respondents declare that they have a university degree or postgraduate degree. When analyzing the level of studies according to age, no differences were detected (gamma coefficient $=-1.115, \mathrm{p}=0.265$ ). On the other hand, differences are detected by clusters. Thus, the alternative tourist segment is characterized by having a lower presence of tourists with university studies (graduate and postgraduate) (statistical $\mathrm{H}$ of Kruskal Wallis $=20,900, \mathrm{p}=0.000)$. The results would support the hypothesis $\left(\mathrm{H}_{4}\right)$ on the greater cultural interest for a WHS by those travellers with a higher academic education.

Regarding the place of origin, national tourism represents $76.4 \%$ of the total number of tourists arriving in the cities of Úbeda and Baeza. On the other hand, 39.4\% of tourists belong to the region where these cities are located, Andalusia. The international tourist represents $23.6 \%$. Of the total of foreign tourists, Germany (15\%), France (7.4\%) and the United Kingdom (4.4\%) are the three countries with the most visitors from all of the twenty different nationalities detected in the investigation. The analysis by segments shows a high level of association between the emotional and cultural interest of tourists and their country of origin (contingency coefficient $=0.364, p=0.039$ ). Thus, the presence of visitors from the region where these two cities are located is much more representative in the emotional tourist cluster than in the rest of the groups, being, therefore, an evidence of the common identity of these tourists: the cultural identity of the Andalusian Renaissance. The analysis of the monthly income by family reveals that $24.4 \%$ of visitors surveyed reported having an income of less than 1,000 euros per month compared to $18.1 \%$ who claim to earn more than 2,500 euros (Table 2).

This is not an obstacle to check that tourists who come to the cities of Úbeda and Baeza have a medium-high purchasing power. Thus, more than half of them declare an income between 1,000 and 2,500 euros per month (31.9\% between 1,000 and 1,500 euros, and $25.7 \%$ between 1,500 and 2,500 euros). In this sense, there are significant differences relating the level of income to the emotional attachment and cultural interest for the destination (statistical $\mathrm{H}$ of Kruskal Wallis $=11,540, \mathrm{p}=0,009$ ).

The average level of income declared by the alternative tourist is $19 \%$ lower than the average, and $25 \%$ lower than that declared by the cultural tourist. On the other hand, there is a positive relationship between the level of family income and the planned expenditure of the visitor (gamma coefficient $=0.174, p=0.000$ ). Thus, tourists who declare higher levels of income spend more money, and conversely, those who declare lower rents have lower spending forecasts. In this sense, the greater purchasing power of the cultural tourist segment translates into a higher planned expenditure, there being differences between the four groups (statistical $\mathrm{H}$ of Kruskal Wallis = 11.837, $\mathrm{p}=0.008$ ). The emotional tourist spends less money than other tourists.

In the opposite direction, those that declare a greater cultural interest for the destination spend more (Table 2). These results support the hypothesis ( $\mathrm{H}_{5}$ ) that tourists with a greater cultural interest generate a greater economic impact on the destination visited (Fields, 2002). In relation to repeating the visit, the segment of tourists with a greater emotional attachment register a somewhat higher index with respect to the rest of the groups since $42.6 \%$ declare they already know the destination (statistical $\mathrm{H}$ of Kruskal Wallis $=16.521 ; \mathrm{p}=0.001$ ). These results may imply that the tourist's emotional experience is associated with fidelity to this destination. 
Jesús Claudio PÉREZ-GÁLVEZ, Tomás LÓPEZ-GUZMÁN, Miguel Jesús MEDINA-VIRUEL, Mónica TORRES-NARANJO

Table 2. Sociodemographic profile of the tourist in Úbeda and Baeza

\begin{tabular}{|c|c|c|c|c|c|c|}
\hline \multirow{2}{*}{ Variables } & \multirow{2}{*}{ Categories } & \multicolumn{4}{|c|}{ Tourist Clusters } & \multirow{2}{*}{ Total } \\
\hline & & \begin{tabular}{|l|} 
Alternative \\
\end{tabular} & Cultural & Emotional & Heritage & \\
\hline $\begin{array}{c}\text { Gender } \\
(\mathbf{N}=\mathbf{5 2 4})\end{array}$ & $\begin{array}{l}\text { Male } \\
\text { Female }\end{array}$ & $\begin{array}{l}56.3 \% \\
43.8 \%\end{array}$ & $\begin{array}{l}59.7 \% \\
40.3 \%\end{array}$ & $\begin{array}{l}64.4 \% \\
35.6 \%\end{array}$ & $\begin{array}{l}47.5 \% \\
52.5 \%\end{array}$ & \begin{tabular}{|l|}
$57.1 \%$ \\
$42.9 \%$
\end{tabular} \\
\hline $\begin{array}{c}\text { Age } \\
(N=522)\end{array}$ & $\begin{array}{l}\text { Under } 30 \\
30-39 \\
40-49 \\
50-59 \\
60 \text { and above }\end{array}$ & $\begin{array}{c}24.5 \% \\
36.7 \% \\
18.4 \% \\
12.2 \% \\
8.1 \% \\
\end{array}$ & $\begin{array}{l}21.4 \% \\
33.2 \% \\
23.6 \% \\
13.5 \% \\
8.3 \% \\
\end{array}$ & $\begin{array}{c}32.7 \% \\
37.5 \% \\
15.4 \% \\
8.7 \% \\
5.8 \% \\
\end{array}$ & $\begin{array}{c}35.0 \% \\
24 \cdot 3 \% \\
18.6 \% \\
17.9 \% \\
4.3 \% \\
\end{array}$ & $\begin{array}{c}27.6 \% \\
32.0 \% \\
20.1 \% \\
13.6 \% \\
6.7 \%\end{array}$ \\
\hline $\begin{array}{c}\text { Academic } \\
\text { level } \\
(\mathrm{N}=\mathbf{5 0 7})\end{array}$ & $\begin{array}{l}\text { Primary education } \\
\text { secondary education } \\
\text { University education } \\
\text { Postdraduate/Master }\end{array}$ & $\begin{array}{c}20.4 \% \\
44.9 \% \\
28.6 \% \\
6.1 \% \\
\end{array}$ & $\begin{array}{c}7.1 \% \\
26.7 \% \\
56.4 \% \\
9.8 \% \\
\end{array}$ & $\begin{array}{c}10.2 \% \\
40.8 \% \\
41.8 \% \\
7.1 \% \\
\end{array}$ & $\begin{array}{c}5.9 \% \\
31.1 \% \\
53.3 \% \\
9.6 \%\end{array}$ & $\begin{array}{c}8.7 \% \\
32.3 \% \\
50.1 \% \\
8.9 \% \\
\end{array}$ \\
\hline $\begin{array}{c}\text { Profession } \\
\text { al category } \\
(N=518)\end{array}$ & $\begin{array}{l}\text { Self-employed } \\
\text { Entrepreneur } \\
\text { Civil servant } \\
\text { Full-time employee } \\
\text { Part-time employee } \\
\text { Freelance } \\
\text { Student } \\
\text { Unemployed } \\
\text { Pensioner } \\
\text { Housewife }\end{array}$ & $\begin{array}{c}22.4 \% \\
---- \\
6.1 \% \\
14.3 \% \\
6.1 \% \\
10.2 \% \\
16.3 \% \\
12.2 \% \\
4.1 \% \\
8.2 \% \\
\end{array}$ & $\begin{array}{c}7.9 \% \\
4.8 \% \\
13.5 \% \\
24.5 \% \\
4.4 \% \\
8.7 \% \\
19.7 \% \\
6.6 \% \\
7.0 \% \\
3.1 \% \\
\end{array}$ & $\begin{array}{c}13.7 \% \\
2.0 \% \\
9.8 \% \\
18.6 \% \\
8.8 \% \\
9.8 \% \\
23.5 \% \\
7.8 \% \\
3.9 \% \\
2.0 \% \\
\end{array}$ & $\begin{array}{c}4.3 \% \\
4.3 \% \\
20.3 \% \\
17.4 \% \\
5.8 \% \\
8.7 \% \\
26.1 \% \\
5.1 \% \\
2.9 \% \\
5.1 \% \\
\end{array}$ & \begin{tabular}{|c|}
$9.5 \%$ \\
$3.7 \%$ \\
$13.9 \%$ \\
$20.5 \%$ \\
$5.8 \%$ \\
$9.1 \%$ \\
$21.8 \%$ \\
$6.9 \%$ \\
$5.0 \%$ \\
$3.9 \%$ \\
\end{tabular} \\
\hline $\begin{array}{c}\text { Income } \\
(\mathrm{N}=455)\end{array}$ & $\begin{array}{l}\text { Less than } 700 € \\
\text { From } 700 \text { to } 999 € \\
\text { From } 1,000 \text { to } 1,499 € \\
\text { From } 1,500 \text { to } 2,499 € \\
\text { From } 2,500 \text { to } 3,499 € \\
\text { More than } 3,500 €\end{array}$ & $\begin{array}{l}22.0 \% \\
17.1 \% \\
26.8 \% \\
26.8 \% \\
7 \cdot 3 \% \\
----- \\
\end{array}$ & $\begin{array}{c}8.4 \% \\
8.9 \% \\
35.5 \% \\
25.1 \% \\
15.3 \% \\
6.9 \% \\
\end{array}$ & \begin{tabular}{|l|}
$11.7 \%$ \\
$17.0 \%$ \\
$36.2 \%$ \\
$22.3 \%$ \\
$5 \cdot 3 \%$ \\
$7.4 \%$ \\
\end{tabular} & $\begin{array}{c}6.8 \% \\
21.4 \% \\
23.9 \% \\
29.1 \% \\
12.8 \% \\
6.0 \% \\
\end{array}$ & \begin{tabular}{|c|}
$9.9 \%$ \\
$14.5 \%$ \\
$31.9 \%$ \\
$25.7 \%$ \\
$11.9 \%$ \\
$6.2 \%$ \\
\end{tabular} \\
\hline $\begin{array}{l}\text { Diary } \\
\text { spend } \\
(N=520)\end{array}$ & $\begin{array}{l}\text { Less than } 20 € \\
\text { From } 21 \text { to } 40 € \\
\text { From } 41 \text { to } 60 € \\
\text { From } 61 \text { to } 80 € \\
\text { From } 81 \text { to } 100 € \\
\text { From } 101 \text { to } 120 € \\
\text { More than de } 120 €\end{array}$ & $\begin{array}{c}4.2 \% \\
12.5 \% \\
14.6 \% \\
25.0 \% \\
27.1 \% \\
10.4 \% \\
6.3 \% \\
\end{array}$ & $\begin{array}{c}0.9 \% \\
9.1 \% \\
16.1 \% \\
27.4 \% \\
27.0 \% \\
16.3 \% \\
3.0 \% \\
\end{array}$ & $\begin{array}{c}5.8 \% \\
15.5 \% \\
22.3 \% \\
23.3 \% \\
23.3 \% \\
6.8 \% \\
2.9 \% \\
\end{array}$ & $\begin{array}{c}2.2 \% \\
15.8 \% \\
19.4 \% \\
23.7 \% \\
22.3 \% \\
8.6 \% \\
7.9 \% \\
\end{array}$ & \begin{tabular}{|c|}
$2.5 \%$ \\
$12.5 \%$ \\
$18.1 \%$ \\
$25.4 \%$ \\
$25.0 \%$ \\
$11.9 \%$ \\
$4.6 \%$ \\
\end{tabular} \\
\hline $\begin{array}{l}\text { Origin of } \\
\text { the tourist } \\
(\mathrm{N}=525)\end{array}$ & $\begin{array}{l}\text { Andalusia } \\
\text { Rest of Spain } \\
\text { Rest of the world }\end{array}$ & $\begin{array}{l}40.8 \% \\
51.0 \% \\
8.2 \% \\
\end{array}$ & $\begin{array}{l}33.2 \% \\
34.5 \% \\
32.3 \% \\
\end{array}$ & $\begin{array}{c}57.3 \% \\
35.0 \% \\
7.8 \% \\
\end{array}$ & $\begin{array}{l}36.2 \% \\
37.6 \% \\
26.2 \% \\
\end{array}$ & $\begin{array}{l}39.4 \% \\
37.0 \% \\
23.6 \% \\
\end{array}$ \\
\hline
\end{tabular}

Among the socio-demographic variables, the main factor that explains the differences in relation to the perception of the historical heritage visited is the country of origin of the visitor (Table 3). These significant differences (the $\mathrm{H}$ statistics of Kruskal Wallis reflects differences in two of the four items at 90\% confidence level) it allows to support that the place of origin of the visitor, and with it their cultural identity, contitions that the emotional experience of the tourist is more or less deep.

Thus, those who share a common cultural identity in relation to the destination visited, that is, tourists who share the cultural identity of the Andalusian Renaissance, in the case of these cities, are much more emotionally involved with the place they visit.

Evaluation of the attributes of the destination

In the questionnaire, which served as the basis for this investigation, a question 
Heritage Tourism in Ubeda y Baeza (Spain).

World Heritage Reinassance Cities

was incorporated with different items that sought to collect the assessment of certain tourist attributes of the destination visited in order to detect strengths and points of improvement (Table 4). The valuation of some of these attributes is not as high as is the degree of general satisfaction since they are very specific aspects in which both personal and social factors come into play. The Cronbach's alpha coefficient (o.826) of the scale reveals a meritorious internal consistency since the critical level (p) associated with Friedman's statistic $\chi^{2}(1,906,008)$ is less than 0.001, which makes it possible to contrast that the means of the elements are not the same.

Table 3. Perception of the historical heritage of tourists visiting the cities of Ubeda and Baeza

\begin{tabular}{|l|c|c|c|c|c|}
\hline \multirow{2}{*}{ Perception } & \multicolumn{3}{|c|}{ Origin of the tourist } & H-Kruskal Wallis \\
\cline { 2 - 6 } & $\begin{array}{c}\text { Andalusía } \\
\text { (average) }\end{array}$ & $\begin{array}{c}\text { Rest of } \\
\text { Spain } \\
\text { (average) }\end{array}$ & $\begin{array}{c}\text { Rest of the } \\
\text { world } \\
\text { (average) }\end{array}$ & $\mathbf{X}^{\mathbf{2}}$ & Sig. \\
\hline $\begin{array}{l}\text { My visit to the historical } \\
\text { heritage of the city moved me }\end{array}$ & 3.70 & 3.68 & 3.53 & 0.649 & $<0.723$ \\
\hline $\begin{array}{l}\text { During my visit I felt as part of } \\
\text { the heritage }\end{array}$ & 2.96 & 2.95 & 2.38 & 20.327 & $<0.000$ \\
\hline $\begin{array}{l}\text { My visit to the historical } \\
\text { heritage of the city made me } \\
\text { feel good }\end{array}$ & 4.20 & 3.97 & 4.01 & 3.883 & $<0.143$ \\
\hline $\begin{array}{l}\text { My visit to the historical } \\
\text { heritage of the city has } \\
\text { contributed to my education }\end{array}$ & 3.71 & 3.77 & 3.94 & 4.721 & $<0.094$ \\
\hline
\end{tabular}

Table 4. Valuation of the attributes of the destination

\begin{tabular}{|c|c|c|c|c|}
\hline \multicolumn{3}{|r|}{ Dimensions and Attributes } & \multirow{2}{*}{\begin{tabular}{|c|} 
Value \\
3.76
\end{tabular}} & \multirow{2}{*}{$\begin{array}{c}\text { Ranking } \\
8\end{array}$} \\
\hline \multirow{7}{*}{ Services } & \multirow{7}{*}{$\begin{array}{c}\text { Average } \\
(3.561)\end{array}$} & Diversity and quality of local gastronomy & & \\
\hline & & Service and quality of tourist accommodation & 3.63 & 11 \\
\hline & & Hospitality of residents & 4.07 & 4 \\
\hline & & Service and quality of restaurants and bars & 3.83 & 6 \\
\hline & & Opportunity to purchase traditional craftwork and food & 3.66 & 10 \\
\hline & & Service and quality of tourist guides & 3.45 & 12 \\
\hline & & Supplementary leisure offer & 2.53 & 15 \\
\hline \multirow{5}{*}{$\begin{array}{l}\text { Historical } \\
\text { and } \\
\text { monumental } \\
\text { heritage }\end{array}$} & \multirow{5}{*}{$\begin{array}{c}\text { Average } \\
(3.955)\end{array}$} & Beauty of the city & 4.36 & 2 \\
\hline & & Monuments and art conservation & 4.23 & 3 \\
\hline & & The city's wealth of monuments and history & 4.41 & 1 \\
\hline & & Tourist information & 3.69 & 9 \\
\hline & & Accessibility to emblematic buildings and monuments & 3.08 & 13 \\
\hline \multirow{3}{*}{ Infrastructures } & \multirow{3}{*}{$\begin{array}{c}\text { Average } \\
(3.464)\end{array}$} & Cleanliness and maintenance of the city & 3.79 & 7 \\
\hline & & Public transport services & 2.71 & 14 \\
\hline & & Citizen security & 3.89 & 5 \\
\hline
\end{tabular}

The set of attributes of these two cities were grouped into three dimensions: Services, Historical and Monumental Heritage, and Infrastructure. The analysis provides an indicator of the importance that travellers attach to the different attributes 
of the cities of Úbeda and Baeza as tourist destinations. Among the attributes that contribute to the satisfaction of the tourist and the image of the destination, "the monumental and historical richness of the city", "the beauty of the city" and "the conservation of art and monuments" stand out. All these attributes belong to the dimension called Historical and Monumental Heritage. Among the attributes that confer a lower competitive advantage to the destination, and that logically it is necessary to work to improve the image of both cities as a tourist destination, the "complementary leisure offer" and the "public transport services" stand out. The analysis by segments reveals, once again, that the valuation is higher among the tourists who have a greater cultural motivation, that is to say, the segments of cultural tourists and patrimonial tourists (Table 5). This conclusion reinforces the recommendation to the enhancement of the cities of Úbeda and Baeza as cultural destinations.

Table 5. Analysis of the tourist attributes of the destination divided by segments

\begin{tabular}{|c|c|c|c|c|c|c|}
\hline \multirow[b]{2}{*}{ Dimensions } & \multicolumn{4}{|c|}{ Tourist Clusters } & \multicolumn{2}{|c|}{ Kruskal Wallis } \\
\hline & $\begin{array}{c}\text { alternative } \\
\text { (Average) }\end{array}$ & $\begin{array}{c}\text { Cultural } \\
\text { (Average) }\end{array}$ & $\begin{array}{c}\text { Emotional } \\
\text { (Average) }\end{array}$ & $\begin{array}{c}\text { Heritage } \\
\text { (Average) }\end{array}$ & $x^{2}$ & Sig. \\
\hline Services & $3.12^{(*)}$ & $3.69^{(*)}$ & 3.48 & 3.56 & 34.220 & $<0.000$ \\
\hline $\begin{array}{l}\text { Historical and } \\
\text { monumental } \\
\text { heritage }\end{array}$ & $\mathbf{3 \cdot 5 2 ^ { ( * ) }}$ & 4.08 & $\left.3.81^{*}\right)$ & 4.01 & 146.464 & $<0.000$ \\
\hline Infrastructures & $3 \cdot 30$ & $3.58^{(*)}$ & 3.38 & 3.38 & 36.193 & $<0.016$ \\
\hline
\end{tabular}

\section{CONCLUSIONS}

The Renaissance heritage present in the cities of Úbeda and Baeza allowed them to be recognized as World Heritage by UNESCO in 2003. For this reason, it is necessary to carry out scientific research in order to provide both public and private managers with information that allows a better understanding about the behavior of visitors in a WHS, as these two Andalusian cities are. This will allow the design of strategies aimed at improving the management of a tourist destination. Consequently, understanding the behavior of visitors is essential for public administrations and the private sector to plan and implement these strategies appropriately.The typologies identified in this research are in line with the models of Poria et al. (2003) and Mckercher (2002): four different segments have been detected. Namely: alternative tourists, cultural tourists, emotional tourists and patrimonial tourists. Likewise, this research concludes that for a large group of travelers the visit to the cities of Úbeda and Baeza is related to their own history and/or culture, and they behave significantly differently from other tourists.

The main practical application of this research work is to contribute to the academic literature, offering tourism experiences in World Heritage cities and analyzing the existing links between visitors and the artistic and monumental heritage (or cultural heritage), as well as to contribute to knowledge about a heritage tourism in the region of Andalusia, with the objective of exploiting the tourist potential of Úbeda and Baeza as cultural destinations, in a sector that every day becomes more competitive in order to attract international tourists (Carvache et al., 2018).

In this sense, it is necessary to adopt actions aimed at improving the less valued attributes, infrastructure and public services in those cities. The main limitation of this investigation is in the temporary period in which this field work was carried out. 
Therefore, it is suggested to extend the research to tourism reached in the cities of Úbeda and Baeza during all the months of the year. As a future line of research, we recommend strengthening research that focuses on other WHS in Spain. Paragraph: use this for the first paragraph in a section, or to continue after an extract.

\section{REFERENCES}

Adie, B.A., \& Hall, C.M., (2017), Who visits world heritage? A comparative analysis of three cultural sites, in Journal of heritage tourism, 12 (1), 67-80.

Al-Rousan, R., Mustafa, M., Almasri, E., \& Bala'awi, F., (2019), Measuring holiday satisfaction of American tourists visiting the dead sea in Jordan, in GeoJournal of Tourism and Geosites, 24 (1), 48-59.

Antón, C., Camarero, C., \& Laguna-García, M., (2017), Towards a new approach of destination loyalty drivers: satisfaction, visit intensity and tourist motivation, in Current issues in tourism, 20 (3), 238-260.

Beerli, A., \& Martín, J.D., (2004), Tourists' characteristics and the perceived image of tourist destinations: a quantitative analysis-a case study of lanzarote, spain, in Tourism management, 25 (5), 623-636.

Bright, C.F., \& Carter, P., (2016), Who are they? Visitors to louisiana's riber road plantations, in Journal of heritage tourism, 11 (3), 262-274.

Bruner, E.M. (1996), Tourism in ghana: the representation of slavery and the return of the black diaspora, in American anthropologist, 98, 290-304.

Carvache-Franco, M., Carvache-Franco, O., Carvache-Franco, W., Villagómez Buele, C., \& Arteaga Peñafiel, M., (2018), The Tourist Demand fromthe Perspective Of The Motivation, Assessment And Satisfaction In A Sun And Beach Destination: The Manta Case, Ecuador, in GeoJournal of Tourism and Geosites, 22 (2), 561-572.

Chandralal, L., \& Valenzuela, F., (2013). Exploring memorable tourism experiences: antecedents and behavioural outcomes, in Journal of Economics, business and management, 1 (2), 177-181.

Chen, G., \& Huang, S., (2017), Towards typology approach an improved to segmenting cultural tourists, in International journal of tourism research, 20 (2), 247-255.

Cheung, S.C.H., (1996), The meanings of a heritage trail in hong kong, in Annals of tourism research, 26 (3), 570-588.

Chi, C.G.Q., \& Qu, H., (2008), Examining the structural relationships of destination image. Tourist satisfaction and destination loyalty: an integrated approach, in Tourism management, 29 (4), 624-636.

Correia, A., Kozak, M., \& Ferradeira, J., (2013), From tourist motivations to tourist satisfaction, in International journal of culture, tourism and hospitality research, 7 (4), 411-424.

Cronbach, L.J., (1951), Coefficient alpha and the internal structure of tests, in Psychometrika, 16, 297-334.

Crouch, G.I., (2011), Destination competitiveness: an analysis of determinant attributes, in Journal of travel research, 50 (27), 27-45.

Driscoll, A., Lawson, R., \& Niven, B., (1994), Measuring tourists' destination perceptions, in Annals of tourism research, 21 (3), 499-511.

Dwyer, L., \& Kim, C., (2003), Destination competitiveness: determinants and indicators, in Current issues in tourism, 6 (5), 369-414.

Fields, K., (2002), Demand for the gastronomy tourism product. motivational factors. In A. M. Hjalager \& G. Richards (Eds.), Tourism and gastronomy (pp. 36-50). Londres: Routledge.

Finn, M., Elliott-White, M., \& Walton, M., (2000), Tourism and leisure research methods: data collection, analysis and interpretation, London: Pearson Education.

Huh, J., Uysal, M., \& McCleary, K., (2006), Cultural/heritage destinations: tourist satisfaction and market segmentation, in Journal of hospitality \& leisure marketing, 14 (3), 81-99.

Kim, A.K., \& Brown, G., (2012), Understanding the relationships between perceived travel experiences, overall satisfaction, and destination loyalty, in Anatolia, 23 (3), 328-347.

Kim, J.H., (2014), The antecedents of memorable tourism experiences: the development of a scale to measure the destination attributes associated with memorable experiences, in Tourism management, 44, 34-45.

Kruskal, W.H., \& Wallis, W.A., (1952), Use of ranks in one-criterion variance analysis, in Journal of the American statistical association, 47 (260), 583-621.

Lew, A.A. (1987), A framework for tourist attraction research, in Annals of tourism research, 14, 553-575.

Mann, H.B., \& Whitney, D.R., (1947), On a test of whether one of two random variables is stochastically larger than the other, in The Annals of mathematical statistics, 50-60. 
McKercher, B., (2002), Towards a classification of cultural tourists, in International journal of tourism research, 4, 29-32.

McKercher, B., \& du Cros, H, (2003), Testing a cultural tourism typology, in International journal of tourism research, 5 (1), 45-58.

Nguyen, T.H.H., \& Cheung, C., (2014), The classification of heritage visitors: a case of hue city Vietnam, in Journal of heritage tourism, 9 (1), 35-50.

Nyaupane, G.P., \& Andereck, K.L., (2014), Visitors to cultural heritage attractions: an activity-based integrated typology, in Tourism culture \& communication, 14 (1), 17-26.

Ozdemir, B., Aksu, A., Etchivar, R., Çizel, B., Çizel, R.B., \& Içigen, E.T., (2012), Relationships among tourist profile, satisfaction and destination loyalty: examining empirical evidences in Antalya region of Turkey, in Journal of hospitality marketing \& management, 21 (5), 506-540.

Poria, Y., Butler, R., \& Airey, D., (2003), The core of heritage tourism, in Annals of tourism research, 30, $238-254$.

Poria, Y., Reichel, A., \& Biran, A., (2006), Heritage site management. Motivations and expectations, in Annals of tourism research, $33,162-178$.

Poria, Y., Reichel, A., \& Cohen, R., (2013), Tourists perceptions of world heritage site and its designation, in Tourism management, 35, 272-274.

Prayag, G., (2008), Image, satisfaction and loyalty-the case of cape town, in Anatolia, 19 (2), 205-224.

Ramires, A., Bradao, F., \& Sousa, A.C., (2016), Motivation-based cluster analysis of international tourists visiting a world heritage city: the case of Porto, Portugal, in Journal of destination marketing \& management, 8, 49-60.

Remoaldo, P.C., Vareiro, L., Ribeiro, J.C., \& Santos, J.F., (2014), Does gender affect visiting a world heritage site?, in Visitor studies, 17 (1), 89-106.

Ribaudo, G., \& Figini, P., (2016), The puzzle of tourism demand at destinations hosting UNESCO world heritage sites: an analysis of tourism flows for Italy, in Journal of travel research, 56 (4), 521-542.

Saipradist, A., \& Staiff, R., (2007), Crossing the cultural divide: western visitors and interpretation at Ayutthaya world heritage site. Thailand, in Journal of heritage tourism, 2 (3), 211-224.

Silberberg, T., (1995), Cultural tourism and business opportunities for museums and heritage sites, in Tourism management, 16 (5), 361-365.

Su, M.M., \& Wall, G., (2011), Chinese research on world heritage tourism, in Asia Pacific Journal of tourism research, 16 (1), 75-88.

Tung, V.W.S., \& Ritchie, J.R.B., (2011), Exploring the essence of memorable tourism experiences, in Annals of tourism research, 38 (4), 1367-1386.

Urry, J., (1990), The tourist gaze: leisure and travel in contemporary societies, Londres: Sage.

Vong, L.T.N., \& Ung, A, (2012), Exploring critical factors of Macau's heritage tourism: what heritage tourists are looking for when visiting the city's iconic heritage site, in Asia Pacific journal of tourism research, 17 (3), 231-245.

*** Chancellery of Economy and Knowledge (2016). Hotel occupation rate survey. Cartography and Statistics Institute of Andalucía. Government of Andalucía.

Submitted:

05.04.2019
Revised:

24.09.2019
Accepted and published online 26.09.2019 